\title{
Políticas compensatórias versus emancipatórias: desafios para implementação de programas de geração de renda às famílias em situação de risco
}

\author{
Elisiane Sartori \\ Faculdade de Tecnologia de Indaiatuba \\ Carlos Henrique Menezes Garcia \\ Faculdade de Tecnologia de Americana
}

\begin{abstract}
A partir de uma ampla pesquisa de campo, junto a famílias pertencentes ao Programa de Erradicação do Trabalho Infantil na cidade de Campinas, buscou-se compreender como vivem e a influência do programa em suas vidas. Para tanto, a argumentação movimentou-se em torno de dois eixos analíticos: em primeiro lugar, mostrou que programas de transferência direta de renda às famílias mais pobres que possuem como contrapartida a inserção e permanência da criança e do adolescente na escola conseguem realmente garantir maior e melhor nível de desempenho escolar. Em segundo lugar, mostrou que programas sociais com vieses mais compensatórios do que emancipatórios não propiciam a autonomia das famílias, o que as deixa numa situação crítica de dependência permanente, podendo até afetar suas próximas gerações.
\end{abstract}

Palavras-chave: família; política social; trabalho infantil; pobreza.

Compensatory versus emancipatory policies: challenges for implementing an income generating program for families at risk

This research aims to understand how families attended by the Childlike Work Eradication Program live and how they are influenced by it. The research is based on an extensive field work. For that, the argumentation moved around two analytical approaches. In first place, it is showed the effectiveness of direct income transfer programs for the poorest families. In exchange these families have to keep their children and teenagers in school, resulting in higher school attendance. In second place, it is showed that social programs focused on compensatory tendencies do not favor the families' autonomy, in comparison to emancipator tendencies. Compensatory tendencies programs actually insert the families into a critical permanent dependency, which can affect future generations.

KEY WORDS: family; social policies; childlike work; poverty.

Artigo recebido em nov. 2010 e aceito em mar. 2011.

RAP - Rio de Janeiro 46(2):425-52, mar./abr. 2012 


\section{Introdução}

Desde a crise econômica mundial que teve lugar em fins dos anos 1970, a família vem sofrendo transformações e sendo reconhecida como um importante agente privado de proteção social. Tanto no Brasil quanto em outros países da América Latina, bem como em boa parte do mundo, a estrutura familiar vem passando por mudanças profundas; é o que podemos chamar de Família Contemporânea. E, a partir de tais transformações, começou-se a se pensar no atendimento ao grupo mais vulnerável que faz parte da família: as crianças. Com isso, entram em cena as políticas de atendimento ao grupo familiar, como programas de redução da pobreza infantil, políticas de valorização das relações familiares, tentativas de diminuição dos riscos de desagregação familiar, entre outras medidas de caráter preventivo e corretivo.

Podemos distinguir, portanto, três grandes períodos na evolução da família, conforme salienta Roudinesco (2003). Numa primeira fase, a família dita "tradicional" serve, acima de tudo, para assegurar a transmissão de um patrimônio. Os casamentos são então arranjados entre os pais sem que a vida sexual e afetiva dos futuros esposos, em geral unidos em idade precoce, seja levada em conta. Nessa ótica, a célula familiar repousa em uma ordem do mundo imutável e inteiramente submetida a uma autoridade patriarcal, verdadeira transposição da monarquia de direito divino. Numa segunda fase, a família dita "moderna" torna-se o receptáculo de uma lógica afetiva cujo modelo se impõe entre o final do século XVIII e meados do XX. Fundada no amor romântico, ela sanciona a reciprocidade dos sentimentos e os desejos carnais por intermédio do casamento. Mas valoriza também a divisão do trabalho entre os esposos, fazendo ao mesmo tempo do filho um sujeito cuja educação sua nação é encarregada de assegurar. A atribuição da autoridade torna-se, então, motivo de uma divisão incessante entre o Estado e os pais, de um lado, e entre os pais e as mães, de outro. Finalmente, a partir dos anos 1960, impõe-se a família dita "contemporânea" — ou pós-moderna —, que une, ao longo de uma duração relativa, dois indivíduos em busca de relações íntimas ou realização sexual. A transmissão de autoridade vai se tornando então cada vez mais problemática, à medida que divórcios, separações e recomposições conjugais aumentam (Roudinesco, 2003:19).

Na esteira de tais mudanças emerge o discurso segundo o qual as famílias estão, nas últimas décadas, passando pela "crise" da família contemporânea. Tal crise tem a ver com o próprio modelo que se idealizou chamar de família. O ponto de partida é o da família nuclear - pai, mãe e filhos. Desta forma, qualquer alteração ocorrida em torno desse modelo é diagnosticada como crise. Portanto, com certeza, o conceito e a própria aplicabilidade do termo têm passado por transformações bastante significativas. Todavia, não podemos falar em único modelo de família, mas em tipos de famílias construídos conforme as regiões, culturas, classes sociais etc.

Parsons, em contraposição, reafirma o modelo da família nuclear ao declarar que se trata de um modelo caracterizado pelo casamento monogâmico e por um número reduzido de filhos, e com atribuição diferenciada dos papéis entre os gêneros masculino e feminino. Nesse sentido, o autor supõe uma total ausência de variedade de modelos de família (Costa, 2005:7). 
Reafirmando este modelo, Bourdieu assegura que a família pode ser apreendida como uma unidade de reprodução social, mediante o processo de transmissão de herança familiar para os filhos: "A família tem um papel determinante na manutenção da ordem social, na reprodução, não apenas biológica, mas social, isto é, na reprodução, na estrutura do espaço social e das relações sociais" (Bourdieu, 1999:31).

A partir das ideias de Bourdieu podem-se considerar as mudanças ocorridas no interior da família não como um sinal de crise, mas sim como resultado de seu caráter estruturante. As famílias à brasileira, por exemplo, têm apresentado uma ampla gama de variações ao longo dos últimos anos. Novos arranjos familiares vêm se constituindo, sejam eles: mães adolescentes solteiras, famílias monoparentais com chefia feminina, família com base em uniões livres (sem o casamento civil ou religioso), famílias formadas por homossexuais com guarda de filhos de relacionamentos anteriores ou filhos adotivos, entre outras. Nesse sentido, a família se configura com um espaço indispensável para a garantia da sobrevivência, do desenvolvimento e da proteção integral dos filhos e demais membros, independente do arranjo familiar ou da forma como está estruturada.

Sendo uma instituição privada e social, a família apresenta aspectos positivos e negativos. A família possui aspectos positivos enquanto apoia seus membros quando necessário e enquanto núcleo de afeto, segurança, solidariedade, amor e suporte emocional. Pode também apresentar aspectos negativos quando a família impõe formas autoritárias, onde se tem o predomínio do individualismo, exploração, violência, falta de respeito, falta de amor e falta de valores (Pasquini, 2005:24).

A família vem sofrendo mudanças internas importantes em virtude do alto grau de transformações econômicas e sociais presenciadas nas últimas décadas. No Brasil, as mudanças mais marcantes se cristalizam e ganham concretude com a promulgação da Constituição Federal de 1988 e as alterações legais contidas no novo Código Civil, que entram em vigor em 2002. A partir de tais legislações, a família passa a ser vista legalmente sob o formato de vários arranjos, com revisões sobre vários temas polêmicos: virgindade, adultério, casamento, sobrenome e regime de bens.

No âmbito das mudanças ocorridas no seio familiar, modificam-se não apenas os arranjos domésticos como também os acordos familiares e a forma como as famílias se inter-relacionam com o Estado, a vida institucional ou econômica, deixando descoberta uma estreita interconexão entre o mundo familiar e outros eixos da organização social. Em sua organização doméstica, as famílias têm recebido os impactos dos recorrentes episódios de crises econômicas, processos de ajustes, reestruturação e abertura do país ao mercado externo, adaptando-se de maneira flexível às várias condições socioeconômicas.

\section{A política social da família}

No Brasil, é possível dizer que se desenvolveu certo tipo de política social, na qual se insere uma "política de família à brasileira". É com relação a essa política de família que iremos nos 
debruçar, identificando seus traços principais. Para Pereira e Pereira (2004), a família sempre fez parte integrante das ações desenvolvidas pelo Estado, mas não como foco de política e sim como corresponsável pelo funcionamento destas políticas públicas.

(...) os governos brasileiros sempre se beneficiaram da participação autonomizada e voluntarista da família na provisão do bem-estar de seus membros. Sendo assim, fica difícil falar da existência de uma política de família no Brasil, assumida pelos poderes públicos, para produzir impactos positivos no seu âmbito. E isso, não porque os poderes públicos tivessem, historicamente, desconsiderado a família, as crianças, os jovens, na sua agenda social, mas porque o desenho das políticas sociais brasileiras sempre foi profundamente influenciado por uma tradição de relacionamento do Estado com a sociedade, que exige desta autoproteção. (Pereira e Pereira, 2004:29)

Esta tendência se acirra e se legitima no Brasil a partir da chegada da concepção conservadora, encampada pelo ideário neoliberal na Europa e nos Estados Unidos, a qual afirmava que a sociedade e a família teriam, desde então, papéis decisivos na redução das desigualdades sociais e ao Estado caberia os "mínimos sociais". Com a crise do modelo de Welfare State a partir dos anos 1980, esta situação se torna cada vez mais comum em países como o Brasil. ${ }^{1}$ Com isso, o governo Collor de Mello inaugura, juntamente com a abertura econômica, a entrada do neoliberalismo na agenda social brasileira e seu sucessor reafirma ainda mais tais ideais, ao deixar a cargo do Estado somente as questões sociais básicas, como foi o caso da criação do Bolsa-Escola, entre outros programas sociais, no referente período.

Com isso, "quem" iria assumir o que antes era realizado pelo Estado e "com que meios", "como" seria realizada a provisão social, "de que forma" seriam estabelecidas as relações entre Estado e sociedade; perguntas feitas num momento de reelaboração do papel do Estado e de redefinição do comprometimento da sociedade e da família. Com este novo desenho da política social, segundo Abrahamson (1992), cada ator passa a ter um papel fundamental de acordo com seus respectivos recursos: o Estado, com o recurso do poder, cabendo-lhe o de autoridade coativa, que só ele possui; o mercado, com o recurso do capital, e a sociedade, da qual a família faz parte, com o recurso da solidariedade. Nesse sentido, o papel das Organizações Governamentais (OGs) e Não Governamentais (ONGs) passa a ser fundamental numa sociedade em que o Estado é cada vez mais mínimo. ${ }^{2}$

A família, nesse entretempo, ficou perdida ante as mudanças sobrevindas, o que criou um impasse em relação ao seu verdadeiro papel, qual seja: agente de sociabilidade e de pre-

\footnotetext{
${ }^{1}$ A crise do Estado de bem-estar social foi caracterizada pelo arrefecimento do crescimento econômico dos países mais avançados, pelo desequilíbrio fiscal e pela perda da legitimidade das políticas sociais públicas, além de revelar-se um atestado inconteste da incompatibilidade da estrutura daquele Estado com a ordem socioeconômica emergente (Pereira e Pereira, 2004:31).

${ }^{2}$ As organizações não governamentais surgem no Brasil, na década de 1990, como uma resposta ao setor público, que não está mais conseguindo atender ao aumento significativo das demandas sociais, advindas do desmantelamento do papel do Estado.
} 
servação do tecido social ou de substituição das ações, até então, desenvolvidas no âmbito do Estado. Nesse sentido, os pesquisadores euro-americanos passam a questionar qual o papel da família diante destas mudanças, conforme destaca Fonseca (2007:15):

No rastro do "declínio de estado de bem-estar social" e do aumento preocupante da pobreza, estes teceram uma crítica à crescente tendência, em política de intervenção, de ver a família como locus privilegiado de problemas e soluções sociais. Críticas acadêmicas aos modelos rígidos de "papéis familiares" baseados na "socialização primária", assim como à centralidade da noção de "autoestima" em programas de intervenção - em suma, o combate a perspectivas vistas como "psicologizantes" - visavam evitar a "culpabilização das vítimas", garantindo que fatores políticos e econômicos encontrassem seu lugar na análise da vida familiar.

Com a minimização do papel do Estado, a família passa a vivenciar esse paradoxo de forma mais densa. Um dos termômetros desta situação é o impacto das transformações econômicas e sociais nas condições de vida da classe trabalhadora através da família. Com efeito, é exatamente no âmbito da família que se efetuará ou não a inserção dos membros adultos no mercado de trabalho. Caso haja situação de desemprego ou subemprego, é na família que se criarão formas de complementação da renda, daí a entrada precoce de crianças e da mulher no mercado. A propósito, Telles (1992) possui uma visão bastante peculiar em relação ao papel da família:

A sociedade brasileira, caracterizada pela lógica da destituição e privação de direitos, tem a família como uma espécie de garantia ética, moral e material, caracterizada pela lógica da destituição e privação de direitos. Dessa forma, a persistência da família como elemento central para a vida dos indivíduos justifica-se diante da despolitização das questões afetas à reprodução social dos trabalhadores, percebida muito mais como questão de ordem privada do que pública, numa tendência de privatização da vida social brasileira. Diante da tendência de despolitização de dimensões significativas da vida social, é no âmbito da família que homens, mulheres, jovens e crianças podem vislumbrar alguma possibilidade de inserção social (Telles, 1992).

Assim, ante as circunstâncias de empobrecimento da população e de situações adversas de desemprego e precarização presentes no mercado de trabalho, é no cotidiano familiar que se aventa a possibilidade real para os indivíduos proverem suas necessidades. Nesse sentido, nesta última década, a família se transformou em centro da política social; um exemplo eloquente disso é a instituição da Lei Orgânica da Assistência Social (Loas), que tomou a família como um dos focos da política de assistência social. Não por acaso, a proteção à família se tornou uma estratégia a ser considerada pela política de assistência social como alvo privilegiado na implementação de diversos programas sociais.

Portanto, a família passa a tomar para si a responsabilidade que, até então, era de ordem pública. Na maioria das vezes, a responsabilidade maior recai sobre as mulheres que, além de desempenhar o papel de chefe de família, são responsáveis pelo cuidado com os filhos, com os idosos, com os doentes e deficientes da família, tendo de suportar uma sobrecarga de trabalho 
que não lhes compete. Na verdade, a família sempre serviu de apoio ao sistema de proteção social brasileiro. Contudo, nestas duas últimas décadas, a estrutura social e econômica sofreu várias mudanças que não condizem com o papel que deveria ser exercido pela família.

Para tanto, se faz necessário entendermos de que modo, em virtude das grandes transformações socioeconômicas ocorridas na última década, que resultaram em altos índices de desemprego, rebaixamento dos salários e precarização das condições e relações de trabalho, a família se transformou em refúgio em face das situações adversas, funcionando como suporte material e de inclusão social (Pereira, 1994).

A partir deste novo cenário, a família não consegue atender às novas demandas e, mais do que isso, substituir o papel do Estado. Com isso, ela passa a ser alvo de políticas sociais focalizadas de vertente compensatória, aplicadas juntamente com programas sociais de corte assistencialista. É óbvio que, dentro deste contexto, de retirada progressiva do Estado, a família não foi capaz de preencher a lacuna deixada por tais formas de intervenção governamental. Com o empobrecimento das famílias na década de 1990, esta situação agrava-se ainda mais, na medida em que a máxima do Estado mínimo expressa-se, no caso brasileiro, por meio das restrições orçamentárias e privatização ou refilantropização da assistência social.

Com efeito, o direito ao não trabalho põe as famílias brasileiras em situação de constante ameaça de sobrevivência, restando-lhes apenas a implementação de programas sociais que lhes garantam um lugar de maior visibilidade e que tenham, em última instância, como objetivo principal, a verdadeira emancipação dessas famílias.

A relação entre Estado e família é de suma importância para o pleno funcionamento da sociedade. De um lado, sabe-se que as medidas de regulação da sociedade promovidas pelo Estado afetam a organização das famílias. Por outro, temos consciência da importância da família para a elaboração das políticas sociais. Este movimento deixa clara a existência de certa dependência mútua entre os mecanismos de ação do Estado e as organizações familiares, conforme Souza (1998) ressalta de maneira bastante coerente:

O sucesso das políticas sociais depende da estrutura da população a que elas se destinam. Por um lado, antes de alcançar os indivíduos, os benefícios concedidos pelo Estado passam por um "filtro redistributivo" do bem-estar, que é a família — regras familiares realocam recursos e responsabilidades à medida que o bem-estar de seus membros é alterado. Por outro, determinados tipos de famílias encontram-se em posição de maior fragilidade na sociedade e, portanto, necessitam de atenção especial. Logo, a eficiência das políticas do sistema de proteção social está diretamente relacionada à sua adequação, à composição e à organização das famílias dos indivíduos protegidos (Souza, 1998:1).

No Brasil, o sistema de proteção social passou a enfocar a questão do atendimento às famílias mais necessitadas de forma mais incisiva nos anos 1990. Esse movimento começa a tomar forma na década de 1970, com a idealização do Programa de Garantia de Renda Mínima. A proposta inicial voltava-se para a erradicação da pobreza no país e promoção do bem-estar social.

Com o crescimento vertiginoso da pobreza na década de 1990, tais programas se tornaram fundamentais na tentativa de minimizar esse cenário. Com cerca de 50 milhões de pes- 
soas vivendo abaixo da linha da pobreza ${ }^{3}$ e poucas expectativas reais de mudança, as famílias tendem a inserir todos os seus membros no mercado de trabalho, incluindo, principalmente, mulheres e crianças. Esse movimento, a longo prazo, irá trazer a estas famílias consequências deletérias e aumentar o risco de reprodução da pobreza.

A única forma de minimizar estes custos sociais tão grandes seria por meio de uma relação de interdependência entre programas de transferência de renda e escola; sem isso estaríamos fadados a uma sociedade cada vez mais pobre e sem perspectiva de quebra do ciclo de reprodução da pobreza. Ao adentrar no mercado de trabalho, na verdade, a criança e/ou adolescente não garante à sua família melhorias significativas na qualidade de vida, pois sua renda é muito baixa por se tratar de trabalhos precários e mal remunerados.

Desta forma, o impacto do trabalho nos níveis globais de pobreza é muito reduzido e não se justifica quando se consideram os efeitos negativos que este irá trazer à vida destas crianças e adolescentes. As perdas ocorridas ao longo da vida dos trabalhadores infanto-juvenis, tanto na saúde física quanto emocional e, principalmente, em termos da formação educacional, são graves, não apenas porque não serão recuperadas facilmente, mas também porque tendem a se propagar intergeracionalmente. Por isso a importância em se atrelarem programas de garantia de renda à educação.

Os primeiros programas de renda mínima implantados no Brasil, a partir de meados dos anos 1990, foram pensados sob este novo enfoque, visão totalmente distinta do que se formulara nos anos 1970. Assim, a família passou a ser a peça-chave de tais programas, sendo "o vínculo familiar, respeitadas as condições de renda, o elemento determinante do acesso ao programa" (Fonseca, 2001:105). ${ }^{4}$ Daí a importância da família na elaboração das políticas sociais implementadas desde então, ou seja, haja vista a importância da família como agente transformador na questão da organização familiar e da garantia de acesso à educação e, mais do que isso, da possibilidade de retirada de seus membros da condição de pobreza.

Ganha força, portanto, a focalização das políticas sociais que considera a família como base do critério de seleção. Porém, deve-se tomar cuidado para que essas políticas não superestimem o peso na definição de seu público-alvo. É certo que, ao se focalizar os programas sobre as famílias pobres, estarão sendo criadas condições favoráveis para que ocorram transformações positivas na educação, propiciando assim uma integração entre a complementação de renda e a permanência da criança e/ou adolescente na escola, o que por sua vez resulta na redução do trabalho infanto-juvenil. De outra parte, a focalização implica a diminuição dos gastos públicos, ao restringir o acesso ao programa às pessoas na faixa etária entre sete e 14 anos de idade.

\footnotetext{
${ }^{3}$ Existem várias faixas para se considerar os indivíduos abaixo da linha da pobreza, porém a mais utilizada refere-se a um quarto do salário mínimo per capita, por família.

${ }^{4}$ Família, para o PGRFM, significa um grupo ligado por laços de parentesco (consanguinidade e afinidade), vivendo sob o mesmo teto e se mantendo pela contribuição de seus membros, ou seja, os recursos que estes aportam beneficiam todos os seus membros (Fonseca, 2001:117).
} 
Nos anos 1990, portanto, o debate sobre focalização e centralidade dos programas sociais ganha ímpeto e se torna prioridade nacional. De acordo com Fonseca (2001), esses programas, ao atrelarem a educação ao complemento de renda, criam a possibilidade de um futuro melhor às crianças e aos adolescentes do país. Quando esses tipos de programas combinam-se com medidas emancipatórias de apoio aos membros adultos das famílias inseridas, conseguem minimizar ainda mais a pobreza extrema e criar uma geração mais autônoma, quebrando, verdadeiramente, o ciclo de pobreza. Somente a partir destas ações, "a pobreza de hoje não produzirá a de amanhã" (Fonseca, 2001:186).

\section{Perfil das famílias atendidas pelo Peti/Campinas}

O trabalho infanto-juvenil cresceu muito na década de 1990, fazendo com que o governo tomasse medidas mais eficazes para seu combate. De acordo com a Pesquisa Nacional por Amostra de Domicílio (Pnad) (IBGE, 2002), cerca de 5,5 milhões de crianças e adolescentes, entre cinco e 17 anos, trabalhavam nas mais diversas atividades. Desses, aproximadamente 300 mil estavam na faixa etária de 5 a 9 anos; 2,8 milhões com idade entre 10 e 15 anos e 2,4 milhões se encontravam entre os 15 e 17 anos de idade. ${ }^{5} \mathrm{O}$ que se viu, desde então, foram ações mais enérgicas com relação ao combate ao trabalho infantil, o que resultou numa redução significativa no país, sobretudo nas regiões Norte, Nordeste e Centro-Oeste.

Ao observarmos esta tendência em nível nacional, os municípios também foram chamados a atuar de forma mais comprometida com o combate ao trabalho infanto-juvenil. Com isso, testemunhou-se nestes últimos anos um significativo crescimento de ações locais, tendo como contrapartida a inclusão e permanência da criança na escola. Campinas foi uma das cidades pioneiras, ao implementar dois programas de referência nacional no combate ao trabalho infantil e na inserção de famílias como principal objeto de foco de política social na área da criança e do adolescente, a saber: o Programa de Garantia de Renda Familiar Mínima (PGRFM) e o Programa de Erradicação do Trabalho Infantil (Peti).

A partir desses dois programas, Campinas, portanto, começou a pensar em uma rede de proteção social mais consolidada, que passasse a atender as famílias de maneira mais sistemática. Não somente a criança e o adolescente se transformaram em meta prioritária de política social, principalmente após a implantação do Peti/Campinas, mas a família passou a ser vista como eixo central no combate ao trabalho infantil. Com a aprovação da Resolução no 6, em outubro de 2001, a família se tornou unidade de referência fundamental. Seus diversos arranjos, momentos de transformação e valores éticos e culturais passaram a ser valorizados e respeitados pelos diversos atores que constituem a rede de atendimento. Ou seja, a ideia é trabalhar a família de forma sistemática, com atenção a todos os seus membros. Nesse

${ }^{5}$ Análise situacional do Programa de Erradicação do Trabalho Infantil — Peti, realizada em 2004, pelo Unicef. 
sentido, as entidades prestadoras de serviços sociais deveriam oferecer programas voltados à família que contemplassem, de forma conjugada, ações compensatórias e emancipatórias.

Nesse sentido, o Peti/Campinas considera família o agrupamento de pessoas que moram na mesma residência, não importando ser pai, mãe, irmão(ã), tia(o), avô(ó). O que interessa para a análise do programa são as relações que unem as pessoas que vivem juntas. Essas relações são baseadas em vínculos financeiros, afetivos, emocionais, ou seja, são vínculos que extrapolam o parentesco e, assim, neste caso, a família se constitui para além dos laços de consanguinidade.

A presente seção contemplará a análise do perfil das famílias atendidas pelo programa Peti/Campinas, pois se sabe de antemão a importância de se conhecer as famílias para a formulação de políticas públicas. O conhecimento da composição e organização dos arranjos familiares é importante para a formulação de políticas públicas por pelo menos quatro grandes motivos: a) as relações entre membros da família podem ter implicações que geram externalidades positivas ou negativas à sociedade; $b$ ) as características das famílias podem ser usadas como critérios de focalização; c) as famílias podem ser usadas para conceber, executar ou controlar programas; e d) as políticas sociais podem tanto afetar como ter seus objetivos afetados pelas diferentes formas de organização familiar (Souza, 1998:2).

Com base nesta justificativa é que iremos expor, mais detalhadamente, as características principais das famílias atendidas pelo Peti/Campinas em seu primeiro ano de funcionamento. As informações analisadas foram extraídas do Cadastro Único dos Programas Sociais do Governo Federal. ${ }^{6}$ Esse cadastro foi realizado junto às famílias atendidas pelo Peti/Campinas no período que compreendeu os meses de fevereiro de 2002 e março de 2003. Ao todo, foram analisadas 79 famílias pertencentes ao programa. São informações que dizem respeito às características do domicílio, ao número de pessoas residentes no domicílio, às despesas mensais (gasto e orçamento domésticos), além de englobarem o estado civil, o grau de instrução e a qualificação profissional do pai e da mãe.

\section{As mães e os pais}

As famílias que teremos como modelo a partir de então, como já discutido no item anterior, passaram por uma série de transformações socioeconômicas e conseguiram chegar ao século XXI mais "maduras", porém mais pobres. Mudaram os valores e a mulher, em seu papel de mãe, ao se transformar no eixo de sustentação dessas famílias. Vários programas sociais começaram a considerar a mãe como figura essencial até para o recebimento da bolsa. Este novo modelo de família tem, em sua grande maioria, a mulher como chefe de família e

\footnotetext{
${ }^{6}$ De acordo com informações retiradas do relatório do Unicef (2004), o Cadastro Único já foi preenchido por $96 \%$ dos municípios brasileiros e se constitui numa importante fonte de informações sobre questões relevantes, como a situação do trabalho infanto-juvenil em âmbito nacional e a análise sobre suas respectivas famílias.
} 
provedora do lar, e não mais somente ao pai é reputado aquele papel. Muda a organização familiar, mudam também as relações intrafamiliares, que não serão abordadas por ora. Neste momento, o objetivo é analisar as famílias atendidas pelo Peti/Campinas apenas sob o aspecto quantitativo.

No que se refere ao estado civil das mães, por exemplo, destacam-se as condições de solteira (29\%) e amasiada (22\%). As mães casadas prevalecem com 32\%, seguidas por viúvas (8\%) e separadas/divorciadas (6\%). Geralmente, as mães solteiras não recebem apoio emocional e tampouco financeiro dos ex-companheiros, e a maioria deles não mantém sequer contato com a família desde que os filhos nasceram. Também vale ressaltar que várias mães casadas estão na terceira ou quarta união conjugal, passando por várias relações amorosas de "pouca" duração temporal.

A faixa etária da mãe se concentra entre 30 e 39 anos de idade. Esses números, quando cruzados com a idade do primeiro filho, mostram que muitas mães engravidaram durante a adolescência, fato este que tende a se reproduzir de geração para geração, pois suas filhas também engravidaram muito cedo, conforme fica patente no depoimento das mães entrevistadas na pesquisa de campo. Outro ponto a assinalar é a baixa incidência de mães mais jovens - com menos de 25 anos — no programa.

A raça/cor ${ }^{7}$ também é um importante fator de análise da condição da mãe na família. A maior parte das mães se autodeclarou de cor/raça branca (43\%), seguida respectivamente de $36 \%$ e $21 \%$ de mães negras e pardas, ao contrário do que é comumente pensado pelo "senso comum" e de acordo com as próprias estatísticas, que apontam a maior incidência de negros entre as famílias mais pobres. Com relação à questão da raça/cor do pai, do total de entrevistados, $52 \%$ se declararam brancos, $30 \%$ negros, $16 \%$ pardos e $2 \%$ amarelos, o que coincide com a análise realizada anteriormente, da raça/cor da mãe.

Um dos temas discutidos de forma recorrente no país é a educação como "fator transformador" das camadas mais pobres da população. No bojo dessa discussão, ao que parece, o Peti tem se constituído em uma grande oportunidade para as crianças e/ou adolescentes se inserirem e permanecerem no sistema educacional, pois a contrapartida do programa consiste na frequência da criança e/ou adolescente na escola. Todavia, ao analisarmos a frequência escolar mínima exigida pelo Programa, tem havido nos últimos anos uma queda no grau de monitoramento da vida das crianças e adolescentes na escola, o que representa uma falha decisiva em um dos principais mecanismos do Peti (Unicef, 2004).

Outra informação relevante a respeito do programa refere-se ao índice de repetência escolar, que ainda é elevado, o que pode indicar um baixo nível de qualidade nas atividades desenvolvidas pela jornada ampliada. O que se percebe, no entanto, é uma visível desarticulação entre a rede de ensino e as organizações locais responsáveis pelo desenvolvimento da jornada ampliada. É corrente a reclamação, segundo a Gerência Nacional do Peti, de ausência de propostas conjuntas entre o sistema educacional regular e as atividades desenvolvidas

\footnotetext{
${ }^{7}$ Essa expressão, raça/cor, foi utilizada no espaço de preenchimento do questionário do Cadastro Único.
} 
pelo Peti (Unicef, 2004). Este é um limite do programa que, com certeza, deve resultar em consequências desastrosas para o futuro da criança e/ou adolescente inserido no sistema de ensino-aprendizagem.

No caso do Peti/Campinas, a situação não é muito diferente da testemunhada no restante do país. Ao analisarmos o grau de instrução da mãe, por exemplo, observa-se uma situação francamente desfavorável à transformação na vida destas famílias via educação. De acordo com os dados, a maior parte das mães (59\%) não terminou sequer o ensino fundamental e 9\% delas eram analfabetas. Esse dado é muito revelador quando se pensa na possibilidade de mudança das condições socioeconômicas destas famílias. Com baixo grau de instrução, esse quadro se acirra com a atual situação do mercado de trabalho: mais exigente, afunilado e discriminatório. As mães são cientes dessa situação e, por isso mesmo, quando inseridas no programa, 90\% delas não permitem que seus filhos deixem de estudar para trabalhar. De acordo com seus depoimentos na pesquisa qualitativa, as mães consideram prioritário a continuidade dos filhos na escola.

Com relação ao grau de instrução do pai, os dados reforçam o que já se havia mencionado em relação às mães. A grande maioria, composta de três em cada grupo de quatro pais que frequentaram a escola, não chegou a completar o ensino fundamental. Mesmo em se tratando de uma proporção elevada, ainda assim é menor quando comparada com o número percentual de mães com esse nível de escolaridade (86\%). Em ambos os casos, o índice de analfabetismo também chama atenção, ao atingir 9\% das mães e 18\% dos pais.

A ausência de políticas públicas de educação no passado, juntamente com a vinda dos pais de regiões muito pobres, levaram ao baixo grau de escolarização, o que compromete a inserção dos pais no mercado de trabalho em condições de lograr postos de trabalho estáveis com rendimentos maiores. Com isso, o sucesso do Peti também passa a ficar comprometido no que diz respeito à sua proposta de eliminar todas as formas de trabalho infantil, pois à medida que os pais têm baixos níveis de escolaridade, é possível supor que isso constitua um obstáculo à transmissão de valores aos filhos no sentido da valorização da educação.

Na pesquisa realizada pelo NEPP — Trabalho Infantil em Campinas —, enfatiza-se também a importância da escolaridade em relação às melhores oportunidades do mercado de trabalho e o melhor êxito em alternativas de geração de renda. Segundo Goldbaum (apud Di Giovanni, 2001:61), "a proporção de crianças e adolescentes ocupados no Brasil e na América Latina declina com o aumento da escolaridade dos pais para todas as faixas etárias".

Outro tema bastante controverso diz respeito aos programas de geração de emprego e renda oferecidos às mães e pais inseridos no Peti. Também faz parte da contrapartida dos beneficiários do programa a participação em cursos de qualificação e requalificação profissional, uma vez que, conforme o Peti, são disponibilizados a todas as unidades federativas recursos destinados à geração de emprego e renda para as famílias inseridas no programa. Entretanto, foi identificado por meio do relatório sobre a Análise situacional do Programa de Erradicação do Trabalho Infantil - Peti, produzido pelo Unicef em 2004, certa resistência 
da maior parte das famílias em participar de programas desta natureza, haja vista o receio de perder a bolsa. ${ }^{8}$

O medo de perder a bolsa, como fator preponderante de limitação da inserção dos beneficiários em projetos de geração de emprego e renda, remete à necessidade de analisar com mais profundidade o grau de eficácia desses projetos, e aponta a relação de dependência estabelecida pelo repasse da bolsa. Todavia, experiências exitosas registradas no país demonstram que os programas de geração de emprego e renda, quando realizados mediante planejamento adequado, dimensionam as potencialidades do programa, superando os desafios.

No que se refere à inclusão dos responsáveis adultos em projetos de escolarização ou educação para adultos, as mães se inserem de forma mais rápida que os pais e estão mais dispostas a participar de programas de geração de emprego e renda, mostrando que o desejo de frequentar tais cursos é mais visível entre elas. Contudo, nem todos os municípios dispõem de uma infraestrutura mínima capaz de viabilizar a implementação de programas tão essenciais nas áreas de geração de renda e educação para adultos.

Portanto, a articulação ineficiente entre as políticas de assistência social e a política de educação é constatada não somente nas atividades de jornada ampliada, mas também na escolaridade e qualificação dos pais das famílias pertencentes ao Peti. Enquanto as ações assistencialistas dominarem tais programas, o escopo de atuação será muito pequeno e atingirá uma quantidade irrisória de famílias. O Peti, como um programa de fortalecimento das relações familiares, deveria dirigir estas ações de maneira mais efetiva, promovendo uma verdadeira política pública de atendimento às famílias em situação de risco social.

Neste sentido, em termos de programas de geração de renda, as tentativas envidadas pelo Peti em Campinas foram muitas - cooperativa de prestação de serviços de limpeza, grupo de "mães de tapioca" —, mas, infelizmente, frustradas com relação à própria efetividade de tais programas, ao não conseguir abarcar um número maior de famílias ou até mesmo alterar suas condições socioeconômicas.

A ausência de qualificação profissional e até mesmo do ensino básico regular, seja por meio da conclusão do primeiro e segundo graus e da educação para adultos, em parte, não permitiu a incorporação das mães em atividades profissionais mais qualificadas e, portanto, com níveis de renda mais elevados. De acordo com os dados do cadastro, com a exceção de algumas poucas mães que trabalhavam como domésticas, cozinheiras ou auxiliares de cozinha no mercado formal de trabalho (13\%), praticamente todas as mães ocupadas estavam inseridas em atividades de subemprego, com relações contratuais de trabalho precárias. Considerando as condições estruturais adversas presentes no mercado de trabalho, este quadro é muito significativo e, de fato, difícil de ser alterado.

\footnotetext{
${ }^{8}$ Dos municípios analisados pelo Unicef, aproximadamente, 73\% informaram haver dificuldades na participação dos pais em programas de geração de emprego e renda, sendo esta dificuldade atribuída, principalmente, em $38 \%$ dos casos, à resistência da família em participar (medo de perder a bolsa); 36\% responsabilizaram a limitação de programas ou projetos; $31 \%$ atribuíram a ausência daqueles; $19 \%$, à dificuldade de acesso aos programas e projetos existentes; e $12 \%$, dada a pouca atratividade de programas e projetos (Unicef, 2004).
} 
Não bastasse o fato de que a maior parte das mães estava envolvida em atividades precárias de trabalho, quase metade delas (45\%) encontrava-se sem qualquer ocupação, desprovidas das condições mínimas que pudessem garantir o sustento de sua família, ainda mais se considerarmos a situação, comum, de desemprego dos pais e de outros membros adultos das famílias. Deste modo, percebe-se que a bolsa do Peti passou a se constituir na principal — quando não a única — fonte de renda dessas famílias.

Níveis reduzidos de escolaridade e ocupações precárias implicam, consequentemente, baixos salários. Entre as mães ocupadas, mais da metade das entrevistadas (58\%) recebia até um salário mínimo e meio. Além de mal-remuneradas, as condições de trabalho eram as piores possíveis, ao apresentarem um alto nível de instabilidade econômica, exatamente por trabalharem em serviços de alto nível de rotatividade de mão de obra. ${ }^{9}$ Ademais, cerca de um terço das mães entrevistadas afirmou estar sem renda no período, o que é preocupante, pois é nesse momento de fragilidade e vulnerabilidade econômica que os pais põem seus filhos para trabalhar com o objetivo de que seja agregado algum recurso ao tão já restrito orçamento doméstico.

Embora o baixo nível de escolaridade seja uma marca da educação formal de pais e mães, os primeiros acabam por se destacar por terem atingido mais anos de estudo, o que se reflete na elevação da qualificação profissional e em melhores oportunidades no mercado de trabalho. Isto é visível nos dados apresentados sobre a ocupação do pai. Praticamente metade do total de pais entrevistados ocupados encontrava-se no mercado formal de trabalho, em diversas atividades ocupacionais: mecânico, pedreiro, ajudante de produção, eletricista, motorista etc. Este número corresponde ao total de pais com carteira assinada, com os direitos trabalhistas assegurados.

Com relação ao nível de rendimentos do pai, verificamos que quase três quartos deles estavam ocupados/com renda (70\%), com apenas 19\% sem ocupação/sem renda e 11\% na inatividade por aposentadoria ou auxílio-licença. No caso dos pais entrevistados, porém, cerca de $45 \%$ recebiam até um salário mínimo e meio e praticamente $80 \%$ auferiam um nível de renda que não chegava sequer a dois salários mínimos.

Isso chama a atenção, mais uma vez, para o fato de que o poder público não deve se preocupar tão somente com o atendimento da população mais necessitada através de políticas compensatórias de transferência de renda, mas com a implementação de programas de geração de renda que proporcionem uma transformação consistente na vida destas famílias, mediante a adoção de políticas emancipatórias que consigam retirá-las do círculo de dependência da assistência social.

Apesar de o programa não discriminar os diversos tipos de família presentes em Campinas, a maior parte era formada por famílias nucleares - pai, mãe e filhos (cerca de $60 \%$ dos lares). Do total das famílias, 44\% dos filhos entrevistados não tinham pai. As demais (56\%)

\footnotetext{
${ }^{9}$ À época da realização do Cadastro Único, o salário mínimo então vigente era de R\$180,00 em fevereiro de 2002 e de $\mathrm{R} \$ 240,00$ em maio de 2003. O valor da bolsa do Peti nesse entretempo não foi alterado, permanecendo em $\mathrm{R} \$ 180,00$.
} 
eram constituídas por filhos que permaneciam morando somente com a mãe ou filhos que moravam com pais ou padrastos e, portanto, muitas vezes tendo irmãos de pais distintos. São o que podemos chamar de "famílias estendidas", muito comuns entre as famílias em questão.

\section{Os filhos}

Quanto aos filhos, o nível de escolaridade das crianças e adolescentes participantes do Peti/ Campinas é um dado importante, pois denota em parte o sucesso do programa em relação aos estudos. É contrapartida do programa a participação e a frequência da criança e/ou adolescente na escola e esta, por sua vez, é monitorada por entidades - OGs e ONGs — que fazem parte do Peti. De acordo com os técnicos do programa, são enviados mensalmente à Prefeitura de Campinas relatórios de acompanhamento de frequência escolar, cujos resultados são satisfatórios, tendo em vista os índices relativamente elevados, que variam entre $80 \%$ e $90 \% .{ }^{10}$

Por outro lado, é visível o atraso etário em relação à série escolar em que deveriam estar. De acordo com o último relatório do Peti (jan. 2005), que incluía o total de 220 crianças atendidas, 57,1\% dos adolescentes de 15 anos estavam atrasados e apenas 15 dos atendidos nunca repetiram o ano. Na idade de 14 anos, 66,6\% estavam atrasados, e de 13 anos, 42,85\% se encontravam nessa situação. Nota-se, portanto, que, na medida em que o filho vai ficando mais velho, maior é sua defasagem escolar. ${ }^{11}$ Em média, cada criança/adolescente atendido possui um ano de atraso escolar.

Com estes dados, podemos concluir que a ocorrência desta defasagem pode ser devido à entrada precoce no mercado de trabalho. Na pesquisa qualitativa realizada, as crianças/ adolescentes afirmaram estar numa situação privilegiada após a inserção no programa, pois podem somente estudar, situação esta totalmente inovadora e produtiva para suas vidas. Pelo contrário, quando trabalhavam e estudavam, afirmaram ser muito difícil conciliar as duas atividades, o que acabava prejudicando significativamente a dedicação aos estudos.

Outro ponto a ressaltar refere-se à idade/trabalho, pois percebemos na análise dos dados quantitativos uma incidência maior no grupo etário entre sete e 16 anos e entre os filhos jovens ou adultos (acima de 18 anos) sem ocupação ou renda. Ou seja, quanto maior a idade do filho, maior o nível de desemprego. Disso podemos concluir que é muito difícil a inserção no mercado de trabalho, posto que as perspectivas de alcançar o chamado "primeiro emprego" estão cada vez mais fora do horizonte dos jovens em questão, o que piora com a situação de baixo grau de escolaridade ou de qualificação profissional. Nesse caso, prevalece o subemprego e as ocupações mais precárias e pouco remuneradas.

\footnotetext{
${ }^{10}$ Um fato a considerar é o sistema de "progressão continuada" implantado no estado de São Paulo, no qual o aluno não é mais reprovado.

${ }^{11}$ De acordo com a pesquisa do IBGE, realizada em 2001, o estado de São Paulo apresenta as seguintes taxas de defasagem idade-série: 7 anos - 14,8\%; 8 anos - 21,3\%; 9 anos - 30,7\%; 10 anos - 29\%; 11 anos - 34,6\%; 12 anos - 42,4\%; 13 anos — 49,1\% e 14 anos — 54,9\% (Di Giovanni, 2001:17).
} 
Segundo pesquisa do NEPP, realizada em 2001, constatou-se que a maioria das famílias que tinham seus filhos menores de 18 anos de idade trabalhando nas ruas de Campinas, no comércio informal, não fazia parte do que se denomina "famílias desestruturadas". Muito ao contrário, as mesmas famílias que, na época da análise do Cadastro Único, encontravam-se inseridas no programa, eram pobres e tinham como objetivo aumentar sua renda e, por isso, organizavam seus filhos para o trabalho infanto-juvenil, quase inexistindo a figura do atravessador de mão de obra. Ou seja, os pais tinham consciência do que estavam fazendo, mas legitimavam e incentivavam a entrada da criança e/ou adolescente no mercado de trabalho, apesar de estarem cientes dos malefícios que o trabalho infanto-juvenil traria para toda a vida de seus filhos, como demonstraram na pesquisa qualitativa.

No que se refere à família como um todo, a análise de alguns dados ainda se faz necessária a fim de complementar as informações já exploradas. Ao comparar os dados relativos ao rendimento familiar com e sem a participação dos rendimentos dos filhos, quando não se inclui a remuneração dos filhos entre cinco e 16 anos, percebe-se que a maior parte das famílias predomina nos estratos até dois salários mínimos, com quase 75\%. Porém, quando computada a participação dos rendimentos dos filhos, a renda familiar abaixo de dois salários mínimos passa a atingir um número sensivelmente menor de famílias (58\%).

Ademais, a participação da remuneração dos filhos na composição do orçamento familiar assume maior importância para as famílias ainda mais pobres, notadamente entre aquelas sem renda e com remunerações abaixo de um salário mínimo. Por outro lado, à medida que sobe o estrato de rendimento, há um aumento significativo da participação da renda dos filhos no orçamento familiar, chegando a dobrar a participação das famílias com renda acima de três salários mínimos. Ou seja, podemos concluir que a participação da renda das crianças/adolescentes é imprescindível para a ampliação do orçamento familiar.

De uma maneira geral, foram analisados vários itens importantes para se entender como se constituem as famílias do Peti/Campinas. Trata-se de famílias com alto grau de vulnerabilidade social e que possuem características condizentes com a maioria das famílias pobres do país, sejam elas: baixo nível de escolaridade, pai e/ou mãe e filhos maiores de 18 anos em situação de subemprego ou desempregados, moradores de regiões periféricas da cidade e sem infraestrutura básica, níveis de renda bastante baixos, constante ameaça de risco social (violência doméstica, alcoolismo, drogadição, conflitos familiares), uma quantidade significativa das famílias chefiada por mulheres. Enfim, são famílias numerosas, constituindo, em média, quatro filhos por família. Os filhos mais novos se constituem, na maioria das vezes, a única renda de toda a família, isso faz que se tornem responsáveis muito cedo, o que provoca também um atraso idade/série.

\section{A percepção do trabalho e do programa pelas famílias}

A análise dos dados da pesquisa quantitativa suscitou um interesse ainda maior em conhecer de forma mais profunda quem são as famílias pertencentes ao Programa de Erradicação do 
Trabalho Infantil de Campinas. Para tanto, com o fito de desenvolver a análise sobre a percepção das mães sobre sua condição antes e depois de receber os benefícios do Peti, levamos a efeito entrevistas em profundidade com uma amostra de sete mães, um número que representa apenas uma pequena parcela do total de famílias atendidas hoje pelo Peti. Contudo, a nosso ver, esse pequeno universo de mães possibilitou recolher um conjunto valioso de informações e, portanto, pode ser tomado como uma "amostra crítica" de sua realidade, na medida em que permitiu conhecer mais de perto as condições objetivas de vida e trabalho destas famílias.

As transformações que ocorreram nas últimas décadas, decerto, afetaram a estrutura familiar de tal forma a nos obrigar a repensar várias questões no âmbito familiar e em suas relações como um todo. As famílias pobres são mais vulneráveis a romper seus laços internos quando existe somente a figura de um único provedor.

Estudos destacam um aumento da incidência da entrada da mulher e dos filhos mais jovens no mercado de trabalho, sobretudo em ocupações do setor informal. Ao mesmo tempo, passam a ganhar mais importância grupos que extrapolam o espaço do domicílio doméstico — amigos, parentes, vizinhos etc. — como elementos fundamentais de ajuda no enfrentamento da falta de recursos entre as camadas mais pobres.

Fonseca (2001:35) sintetiza bem as mudanças ocorridas no âmbito da família neste período:

A organização social dos domicílios e famílias, estritamente relacionada com os sistemas e as condições do mercado de trabalho, é sensível a políticas macroeconômicas, daí a preocupação com a atual conjuntura de precariedade de empregos, altas taxas de desemprego e baixos salários para uma maioria dos trabalhadores. A capacidade de os homens adultos atuarem como provedores diminuiu ainda mais nos anos 90, da mesma forma que o papel que os jovens desempenhavam como fonte de recurso adicional na família tende a desaparecer através do desemprego e migrações. A força de trabalho feminina, uma vez mais, aparece como um dos poucos recursos disponíveis para a sobrevivência de muitas unidades domésticas.

Se, de fato, ocorreram várias mudanças no mercado e nas relações de trabalho, é na família, portanto, que essas condições adquirem materialidade e são transformadas, delineando o modo como as situações adversas, relacionadas à pobreza, se inscrevem no cotidiano familiar. Assim, em um contexto social marcado pelo aumento do desemprego, no qual se torna cada vez mais difícil a obtenção do trabalho assalariado e, por consequência, o acesso à cidadania, a família vem se convertendo, talvez, em quase a única possibilidade real para os indivíduos proverem suas necessidades, principalmente diante da inoperância ou mesmo ausência de mecanismos de proteção social que levem em consideração os efeitos sociais recentes dos problemas originados da precarização do trabalho (Alencar, 2004:63).

Na ausência de um verdadeiro sistema de proteção social, é na família que os indivíduos tendem a buscar recursos para lidar com as circunstâncias adversas. A partir da grave crise econômica estabelecida no início dos anos 1990, expressa em desemprego crescente, rebaixamento de salários, precarização das condições e relações de trabalho, desregulamentação 
de direitos sociais, observa-se uma fragilidade da família em dar conta desta ampla gama de demandas sociais. O Estado, com isso, não pode simplesmente sobrecarregar as famílias, mas, sim, fornecer as condições mínimas para sua sobrevivência, reputando-lhes papel central na elaboração de políticas públicas eficazes, ao torná-las alvo de políticas que realmente levem em consideração as novas configurações da questão social no país.

Nesse sentido, a política de atendimento das famílias do Peti/Campinas necessita de uma melhor elaboração e efetividade que consiga proporcionar condições mínimas de acesso ao emprego, já que elas se encontram em uma situação extremamente frágil economicamente, muito empobrecidas e sem muitas possibilidades de uma melhor inserção no atual mercado de trabalho. Abaixo, relacionamos alguns relatos bastante importantes falados durante a realização da pesquisa qualitativa.

Daí quando eu vim para Campinas, comecei a trabalhar em casa de família, só que eu tenho muita mágoa, porque eu trabalho aqui desde 1979 e nunca achei um lugar que a pessoa me registrasse, que me desse um nome. Já cuidei de velho, idoso por dois, três anos na mesma casa, as famílias tratavam bem, só que não valorizam o trabalho, não registram a gente. Trabalhei em lanchonete, sei cozinhar bem, mas tudo sem registro, os chefes nunca me valorizaram. Eu não tive sorte para o trabalho. ${ }^{12}$

Todas as mães se encontravam desempregadas no período da entrevista, até mesmo porque tinham sido cadastradas para fazer parte do "Grupo de Mães da Tapioca", o qual se formou como uma tentativa de criar uma cooperativa ou um grupo associativo. Assim, podese considerar uma situação exclusiva do grupo de mães entrevistadas à época, mas não necessariamente que todas as famílias do programa se encontrem na condição de desemprego. Porém, é notável que a maioria das famílias pobres, atualmente, no Brasil, encontra-se numa situação bastante desfavorável em termos de contrato formal de trabalho e salários mais dignos. Ao contrário disso, são cada vez mais comuns os contratos precários de trabalho e de pouca duração.

Teve uma época que nós dois ficamos desempregados. Daí nós passamos fome com as duas crianças e, infelizmente, nós voltamos pra rua pra pedir dinheiro. Não tinha leite, não tinha nada para comer. Meu marido chegava em casa, ele chorava porque não tinha nada pra comer. O pouco de comida que tinha, a gente cozinhava no fogão à lenha porque não tinha gás. Daí eu falei para o meu marido que a gente ia conseguir um lugar pra ficar, daí a gente veio a pé de São Paulo pra Souzas. Daí que a gente conseguiu uma casa pra cuidar e passamos a morar lá. ${ }^{13}$

Meu marido sempre me ajudou muito, ele é que cuidava das crianças para mim. Hoje, ele não trabalha, está encostado pelo INSS, no auxílio-doença, só recebe a pensão que é dois salários-mí-

\footnotetext{
${ }^{12}$ Entrevista com dona Maria dos Anjos, em 10 de julho de 2003, em Campinas (SP).

${ }^{13}$ Entrevista com dona Eunice Maria, em 13 de agosto de 2003, em Campinas (SP).
} 
nimos. Faz cinco anos que ele está com problema nos rins. Ele gasta bastante com remédios. No início do casamento, a gente teve momentos de grande necessidade, ele foi mandado embora e eu tinha perdido o nenê, não podia trabalhar, daí nós passamos muita necessidade, muita fome, sabe o que é você fazer uma polenta e fritar com um restinho de óleo e fazer um café e dividir um pedacinho pra cada um, só pra não dormir com fome? ${ }^{14}$

As famílias em análise, envolvidas por uma atmosfera de conflitos, têm na assistência social um dos caminhos para a resolução de problemas, acalentando o desejo de participar de um programa social que lhes propicie o mínimo para sua sobrevivência e, consequentemente, para obter os recursos mínimos para garantir sua subsistência, recorrem a outros expedientes. Além da entrada maciça da mulher no mercado de trabalho, como vimos, os outros membros das famílias são chamados a auxiliar no orçamento doméstico: as crianças e os adolescentes.

Porém, o elemento econômico não é o único fator determinante na inserção da criança no mercado de trabalho. Em alguns casos, o trabalho infantil também é sensível a uma multiplicidade de fatores que emergem, por exemplo, das relações familiares — maus-tratos, violência, abusos físico e sexual —, que acabam por se catalisar e se potencializar em situações de pobreza. Com isso, as crianças dividem o espaço socializador e lúdico com o trabalho e a aprendizagem de práticas sociolaborais (Lezcano, 1998).

Nesse sentido, é inegável, dentro deste contexto, a influência da família na determinação da entrada da criança no mundo do trabalho. Moura (1988) admite serem três fatores que propiciam essa ocorrência, a saber: a) o complemento da renda familiar; b) a necessidade de profissionalização; e c) a liberdade de consumo.

Muitas famílias chegam até a proporcionar um ambiente favorável para que a criança comece a trabalhar. Muitos são os motivos internos, de "desestruturação" familiar — como o alto índice de pais separados, a desagregação familiar, brigas, drogas, violência, e a "síndrome da casa vazia"15 —, e externos (alto índice de desemprego, trabalho informal, baixos salários) que acirram ainda mais esse quadro, o que facilita a entrada da criança no mercado de trabalho.

Contudo, é na família que se tem a oportunidade de reconstruir o aspecto multifacetado da pobreza, desviando-se, assim, de uma noção genérica e homogeneizadora da pobreza, posto que na família também são variadas as formas de inserção no mercado de trabalho. Se o desemprego, o trabalho desqualificado e as remunerações insuficientes estruturam o cenário potencial de precariedade de vida, é na família que essas condições adquirem materialidade e são transformadas, ao delinear o modo como as situações adversas, relacionadas à pobreza, se inscrevem no cotidiano familiar.

No caso das famílias em análise, a entrada da criança e/ou adolescente no mercado de trabalho ocorre sem grandes problemas. A maioria das mães entrevistadas enxerga com na-

\footnotetext{
${ }^{14}$ Entrevista com dona Ângela Maria, realizada em 10 de julho de 2003, em Campinas (SP).

${ }^{15}$ A "síndrome da casa vazia" diz respeito à quase total ausência dos pais e/ou mães que trabalham durante o dia todo, deixando seus filhos menores com os mais velhos, às vezes quase da mesma idade.
} 
turalidade o fato de os filhos trabalharem, até mesmo por conta de suas próprias histórias de vida pregressas, que tiveram no trabalho infantil um meio de sobrevivência.

Com 10 anos, a Viviane veio ajudar o pai quando ele virou camelô, que ele não tinha como deixar a banca sozinha. Aí ele trazia ela para ajudar. Agora que ela está no Peti, não vem mais trabalhar, mas querer ela quer e chega até falar que quer vir trabalhar na cidade porque pode almoçar fora, ganhar as coisas das pessoas. Ela gosta de ficar com o pai dela. ${ }^{16}$

A minha filhinha Silvana, de quatro anos, já enchia sacolinha mais eu. Eu adubava a terra, abria a terra, daí ela jogava as mudas com a sacolinha. Fazia todas as fileiras. Sacolinha para fazer as mudas para plantar. Daí eu sempre levava ela comigo. Eu achava normal, porque eu também trabalhei desde criança, é bom para eles aprenderem a ter uma profissão. ${ }^{17}$

Observamos, portanto, que uma das principais causas do trabalho da criança é a ausência de recursos financeiros para sustentar a unidade doméstica. Quando existe ausência ou escassez de recursos, a criança e/ou adolescente se sente mobilizado a buscar esta renda. Nesse sentido, se sujeita a qualquer tipo de serviço, por pior que ele se apresente, em busca de uma renda para auxiliar no orçamento doméstico. Os pais, como vimos, ao legitimarem este tipo de situação com normalidade, são os interlocutores no encaminhamento dos filhos ao mercado de trabalho. Deste modo, a inserção é feita de forma tranquila e o complemento da renda é muito bem aceito, conforme afirmam nossas entrevistadas ao se depararem com o questionamento acerca ao trabalho infanto-juvenil.

A Priscila trabalhou de empregada doméstica para a filha da mulher que eu trabalhei quando eu tinha 11 anos de idade. Eu coloquei ela lá porque a gente nunca teve condição de dar nada para eles, então a gente arrumava esse "servicinho" para ela porque ela queria se arrumar, queria as coisas, até na escola o material era ganhado de esmola. ${ }^{18}$

Apesar de as mães incentivarem a entrada precoce de seus filhos no mercado de trabalho, elas reconhecem os malefícios do trabalho infanto-juvenil, e mesmo passando por grandes dificuldades financeiras, entendem que os estudos devem ser a prioridade. A educação é tida como fundamental para criar alternativas de uma vida melhor e uma oportunidade única de quebra do ciclo de pobreza existente nestas famílias. É a possibilidade de garantir um futuro com menos restrições e conflitos e aí, sim, estar preparado para as dificuldades de outra maneira.

O Rodrigo vê o pai dele nessa situação, tendo que comprar muitos remédios e não tem dinheiro, daí ele fala que quer sair do Núcleo, quer trabalhar. Ele estuda de manhã, está na 6ª série, e vai

\footnotetext{
${ }^{16}$ Entrevista com dona Eunice Maria, em 13 de agosto de 2003, em Campinas (SP).

${ }^{17}$ Entrevista com dona Maria dos Anjos, em 10 de julho de 2003, em Campinas (SP).

${ }^{18}$ Entrevista com dona Ana Oliveira, realizada em 17 de julho de 2003, em Campinas (SP).
} 
no Núcleo à tarde. Ele fala que quer trabalhar, mas eu não deixo, eu não vou explorar o meu filho. No meu tempo era diferente, eu não tinha um pai que me dava tudo, mas o que eu quero para ele é que ele tenha mais tarde uma profissão que ele ganhe bem. ${ }^{19}$

Nesse sentido, no universo de nossas entrevistadas a educação surge como um bem valioso, com a real possibilidade de acesso às melhores oportunidades de trabalho, maior nível de remuneração e um emprego mais digno. Uma melhoria no nível educacional e, consequentemente, na oportunidade de emprego requer, todavia, uma melhor qualificação que, necessariamente, está associada à realização de cursos profissionalizantes que deem conta de facilitar e promover essa inserção no mercado de trabalho.

Contudo, o que se tem é uma ausência de cursos oferecidos pelo poder público, que não consegue atingir o mínimo de atendimento a essa demanda tão expressiva. Desta forma, percebe-se nas falas das mães certa indignação com relação à sua incapacidade de pagar um curso profissionalizante, tão necessário e urgente, aos seus filhos adolescentes e, mais uma vez, se sentem muito frustradas em relação a essa situação.

É o dinheiro o que mais dificulta, se eu tivesse um emprego bom que eu pudesse ganhar, que eu pudesse dar o melhor para os meus filhos. Igual a Kelly, ela já está mocinha, ela quer fazer um curso, condições de dar para ela, eu não tenho, só se for mais tarde. Só se for depois, guardar um dinheiro para ela poder fazer um curso, para profissionalizar, ter uma profissão melhor, porque hoje se você não tem profissão, não tem trabalho, então tudo isso aí eu me preocupo mais! Então, porque eu não quero o que eu passei e o que estou passando, porque não tem serviço para quem não tem estudo. ${ }^{20}$

Nesses relatos, a educação aparece como fundamental, porém trabalhar também o é. Daí, o aspecto cultural da valorização do trabalho que está embutida na raiz da estruturação familiar, ou seja, meu filho tem de estudar até uma certa idade - no caso, correspondente ao ensino básico - , que seria entre sete e 14 anos. Depois disso, se faz necessário combinar estudo (provavelmente, noturno) com trabalho. Assim, a maior importância dada à educação se restringe apenas àquela que garanta um mínimo de estudo para a inserção no mercado de trabalho. Além do mais, também ao passar a trabalhar e estudar, minimizam-se as chances de os filhos entrarem no mundo do crime, da drogadição, pois estarão com o tempo quase todo preenchido com as atividades educativas e de trabalho.

Se pudesse colocar esses meninos para trabalhar de pequeno, a partir dos 12 anos, eu acho que não existiria tanta marginalidade. Não um trabalho na rua, ter um local para se profissionalizar, aprender um ofício. Hoje em dia, você não pode colocar uma criança para trabalhar desde os 10

\footnotetext{
${ }^{19}$ Entrevista com dona Ângela Maria, realizada em 10 de julho de 2003, em Campinas (SP).

${ }^{20}$ Entrevista com dona Eunice Maria, em 13 de agosto de 2003, em Campinas (SP).
} 
anos. Eu comecei meu curso de corte e costura com 7 anos, fiz bordado a mão, fiz culinária, e nem por isso eu morri. Por que hoje em dia os adolescente não podem nem aprender, só depois dos 14 anos? Eu acho errado isso! ${ }^{21}$

A pobreza, na percepção das entrevistadas, está aumentando devido à falta de emprego e ao aumento de exigências (escolaridade e qualificação profissional) para a admissão em um trabalho. Sob o ponto de vista das mesmas, está cada vez mais difícil conseguir uma oportunidade de emprego e os salários são irrisórios. O que resta a estas famílias são os programas sociais de transferência de renda, disseminados no país na década de 1990, que lhes garantem um mínimo de sobrevivência.

\section{Consequências e impactos do Peti em Campinas}

O grande nó do Peti reside nos programas de geração de emprego e renda voltados aos responsáveis das famílias atendidas. Em Campinas, essa área do programa pode ser considerada extremamente limitada em sua forma de atuação. As famílias inseridas no Peti apresentam um alto grau de vulnerabilidade econômica e social que não permitem que participem de uma estrutura mínima de cidadania. Nesse sentido, programas focados na (re)qualificação profissional e que fomentem oportunidades de inserção no mercado de trabalho são primordiais para que se interrompa o ciclo da pobreza que se reproduz de geração em geração. A técnica do programa descreve bem o perfil da família que faz parte do Peti/Campinas.

São famílias com baixo nível de escolaridade, que moram na periferia da cidade, em situação muito precária. Muitas famílias moram em barracos, às vezes não conseguem pagar uma conta de luz, muitos têm luz clandestina, o que é um risco! São famílias que, na maioria das vezes, os pais estão desempregados, é raro você encontrar uma família que possui alguém com carteira assinada. Famílias que estão envolvidas com a criminalidade e com a violência. Você vê muitas famílias que têm o pai e o filho mais velho preso e, como já falei, famílias cujos pais trabalharam na infância. Isso é muito comum! São vários os conflitos familiares. A maioria das famílias são chefiadas por mulheres, as quais condensam o papel de mãe e pai, ao mesmo tempo. Vários tipos de arranjos familiares. ${ }^{22}$

As famílias atendidas pelo Peti já passaram por outros programas sociais e, em sua grande maioria, gostariam de estar, no futuro, incluídas em outros programas. Esse fato revela um tipo de assistencialismo que dificilmente será superado sem a autonomização dessas famílias. Pois se não se criarem mecanismos de intervenção que possam livrar essas famílias da

\footnotetext{
${ }^{21}$ Entrevista com dona Marlene Ribeiro, em 10 de julho 2003, em Campinas (SP).

${ }^{22}$ Entrevista com a técnica do Peti, Ana Vitória, realizada em 23 de novembro de 2004, em Campinas (SP).
} 
situação de extrema pobreza, elas continuarão dependentes do sistema mínimo de proteção social. Desta forma, todo o esforço que está se fazendo não está surtindo efeito. Por um lado, o investimento é muito alto, e as respostas muito lentas, o que acaba por aumentar o grau de dependência das famílias em relação ao poder público. De outro lado, o sistema de proteção social não suporta demanda tão expressiva.

Quando eu trabalhava no Renda Mínima não tinha essa quantidade de famílias fragilizadas que tem no Peti. As famílias do Peti são mais vulneráveis do que as do Renda Mínima, em nível de dinâmica e de violência. O que eu observo é que em muitas famílias do Renda Mínima, que hoje estão sendo atendidas pelo Peti, a situação se agravou. Uma família, por exemplo, que eu atendi no Renda Mínima, no final do atendimento, achei que a mãe estava começando a melhorar, procurando um trabalho. Entrei no Peti, fiquei sabendo que a família estava incluída no programa. Fui visitar e vi a família numa situação calamitosa, de moradia, de renda, o pai havia morrido, a mãe começou a beber. É difícil saber se as famílias estão piorando, mas na minha percepção eu acho que uma parcela significativa está piorando mesmo! ${ }^{23}$

Ao que tudo indica, de acordo com a fala reproduzida acima, percebe-se que o PGRFM atendia famílias com menor grau de vulnerabilidade social. O Peti, por sua vez, encerra outra dinâmica, ao lidar com estruturas familiares também compostas de crianças e/ou adolescentes trabalhadores. O PGRFM tinha como principal critério de seleção a renda da família, num valor que girava em torno de $\mathrm{R} \$ 35,00$, como é até hoje. O Peti, ao focar o trabalho infanto-juvenil, atende famílias mais fragilizadas, que, por alguma razão, tiveram de colocar seus filhos para trabalhar. No PGRFM, as crianças e adolescentes não necessariamente trabalhavam e as famílias, em virtude do desemprego e dos baixos salários, recebiam uma renda complementar para garantir sua sobrevivência. No Peti, além disso, de acordo com as entrevistas realizadas, observou-se um índice elevado de violência e conflitos familiares intensos, tornando as famílias aparentemente mais frágeis não apenas do ponto de vista econômico, mas também emocional.

Existe uma lacuna entre a formulação do programa e sua implementação na prática. Os idealizadores do Peti talvez não tenham imaginado o tipo de família e de situações que iriam enfrentar. No dia a dia, os gestores e técnicos do programa estão encontrando várias dificuldades, as quais o formato do Peti não dá conta de atender, o que repercute negativamente nos resultados desta política pública, como a violência doméstica, a drogadição e a criminalidade. Nesse sentido, a supressão do hiato existente entre a formulação do Peti e seu processo de implementação requer, afora outras medidas, o redesenho do programa mediante o estabelecimento do diálogo mais estreito e permanente entre avaliadores, gestores e coordenadores do programa.

\footnotetext{
${ }^{23}$ Entrevista com a técnica do Peti, Ana Vitória, realizada em 23 de novembro de 2004, em Campinas (SP).
} 
Esse quadro se acirra ainda mais quando a criança e/ou adolescente não desperta o interesse de frequentar as ações desenvolvidas na Jornada Ampliada. ${ }^{24} \mathrm{Nem}$ todas as entidades possuem atividades atraentes para a faixa etária entre 15 e 16 anos. Não existe no país uma política nacional de atendimento ao adolescente nesta idade, o que se traduz em um vazio cujo desdobramento pode ser o abandono das OGs e ONGs. Seja como for, sem frequentar as atividades da jornada ampliada, muitas vezes já concluído o ensino médio, estes adolescentes ficam, por exemplo, mais suscetíveis à vida na criminalidade.

Segundo a técnica do Peti/Campinas, há uma parcela relevante de adolescentes, numa proporção entre $20 \%$ e $30 \%$, que se nega a participar das atividades de jornada ampliada. Ademais, boa parte daqueles que frequentam tais atividades não está, de fato, envolvida pela proposta preconizada nesta área do Peti, mas tão somente para que não haja o desligamento da sua família do programa, pois existe uma negociação entre o adolescente e o órgão gestor para que o primeiro compareça, ao menos duas vezes por semana, em algumas atividades, não necessariamente todas.

Quando há um vínculo forte da criança e/ou adolescente com a rua, torna-se bem mais difícil fazer com que eles permaneçam nas atividades oferecidas pelo programa. Como vimos, $10 \%$ das crianças e dos adolescentes participantes do Peti/Campinas ainda insistem em trabalhar nas ruas, no comércio informal. Por mais que se conscientizem as famílias sobre as consequências deletérias do trabalho infanto-juvenil, algumas delas ainda continuam permitindo que seus filhos trabalhem, sem, contudo, abandonar a escola.

Daí a importância de estes programas também deslocarem seu foco para as ações sociais emancipatórias. Ao possibilitar trabalho digno aos membros adultos das famílias, podem-se criar condições mais favoráveis à mudança na forma de enfrentamento da pobreza, chegando a ponto de não permitir mais que seus filhos trabalhem em ocupações precárias e exploratórias. Programas de geração de emprego e renda poderiam, nesse sentido, jogar um papel decisivo na retirada definitiva dessas crianças e adolescentes do comércio informal das ruas de Campinas.

Em que pese a imposição destes limites, comuns a vários programas sociais implantados no Brasil, o Peti/Campinas tem conseguido atingir de forma positiva as famílias atendidas. Assim, o sucesso relativo do programa começa no valor da bolsa, passa pelo atendimento prestado aos filhos pela Rede Executora e termina na maior sensibilização dos pais a respeito dos riscos e males inerentes ao trabalho infanto-juvenil. Este é, sem dúvida, um ponto bastante positivo, uma vez que se constitui num dos vetores da mudança de cultura de uma sociedade que considera conveniente as crianças e os adolescentes trabalharem.

Eu fiz a avaliação com as famílias, deu a impressão que a resposta foi positiva. Eu acho que a gente não precisa pensar somente na qualidade de vida, mas na própria cultura enraizada. A

\footnotetext{
${ }^{24}$ A Jornada Ampliada refere-se a um programa de complementação de horas, em que a criança e/ou adolescente pertencentes ao Peti deverão cumprir para terem acesso a uma série de atividades complementares e à bolsa.
} 
gente vem conseguindo mudar a forma destas famílias pensarem o trabalho infantil. Quando eu faço reuniões com os responsáveis, eu faço eles lembrarem da época da infância. A maioria deles trabalhou quando era criança. Foi até emocionante vê os relatos, muitos deixaram de estudar, alguns tiveram graves problemas de saúde por causa do trabalho infantil. Então, eles reconhecem como é importante que os filhos não trabalhem. ${ }^{25}$

Durante a pesquisa de campo qualitativa, solicitamos aos entrevistados que apontassem dois pontos positivos e dois pontos negativos relacionados ao Peti/Campinas. Com relação aos aspectos negativos, destacam-se o baixo valor da bolsa e a idade mínima para entrar no programa, de sete anos. Em contrapartida, como pontos positivos do programa, foram mencionados a retirada do filho do trabalho no comércio informal; a participação nas atividades oferecidas na Jornada Ampliada; o valor da bolsa, que contribui para o equilíbrio do orçamento doméstico; e a melhoria no relacionamento familiar.

Já as sugestões apresentadas pelos informantes centraram-se em torno da melhoria do programa. A principal referia-se ao aumento do valor da bolsa, por ser considerada defasada em relação ao salário mínimo. Outras sugestões pontuais envolveram questões como o aumento do número de visitas da assistente social, meio de transporte que facilite o percurso da residência até o núcleo que o filho frequenta, o complemento da renda da bolsa com uma cesta básica para a família, a criação de mais cursos de qualificação profissional destinados aos responsáveis e adolescentes e ampliação do número de vagas dos mesmos. A maioria dos entrevistados não apresentou sugestões.

Finalmente, perguntamos aos entrevistados o que havia mudado em sua vida familiar após o ingresso no Peti/Campinas. Percebe-se, pelas respostas, que houve uma melhora sensível nas condições econômicas, já que passaram a contar com uma renda fixa ao final de todo mês. Nesse sentido, a concessão da bolsa às famílias tornou-as mais capazes de administrar o gasto doméstico e, mais do que isso, permitiu o acesso à alimentação adequada e ao consumo de alguns tipos de bens que antes não podiam comprar. ${ }^{26}$

De outra parte, o fato de os filhos não terem mais que se submeter ao trabalho nos semáforos, bem como a outras formas de ocupação, foi apontado como uma mudança de relevo. Também nota-se pelos depoimentos dos entrevistados uma mudança positiva nas relações que permeiam as relações familiares. Ao que parece, os conflitos característicos presentes na vida daquelas famílias estão dando lugar a uma atmosfera mais harmoniosa às relações entre pais, mães e filhos. Existe, enfim, o reconhecimento da importância que o programa teve em vários aspectos de suas vidas.

Um dos maiores receios dos representantes das famílias do Peti é o atraso no pagamento da bolsa. No período entre 2000 e 2003, houve certa estagnação em termos de atendimento

\footnotetext{
${ }^{25}$ Entrevista com a técnica do Peti, Ana Vitória, realizada em 23 de novembro de 2004, em Campinas (SP).

${ }^{26}$ Estes bens referem-se à compra de gás, material escolar, alimentos da cesta básica, além de poderem fazer crediários, com prestações fixas.
} 
e diminuição dos recursos financeiros. Para se ter uma ideia, no primeiro ano de execução do Peti, em nível nacional, o atendimento cresceu cerca de 3.000\%. De 1999 até 2001, o programa apresentou um crescimento de cerca de $500 \%$ em termos de atendimento e $350 \%$ de recursos aplicados. A ampliação da cobertura do programa, entre 2001 e 2003, em termo de atendimento, implicou a inserção de apenas 59.795 crianças e adolescentes, o que representou um incremento relativo muito pequeno e, portanto, uma desaceleração pronunciada do número de atendimentos e do volume de recursos aplicados no programa (Unicef, 2004).

Contudo, a diminuição dos recursos não afetou diretamente o público atendido pelo Peti, já que se estima que o maior impacto da redução tenha recaído sobre a jornada ampliada e outras ações desenvolvidas pelo programa, em especial aquelas voltadas para a geração de emprego e renda, limitando ainda mais seu alcance.

O Programa Peti em Campinas, apesar dos limites comuns a tantos outros municípios do país, vem conseguindo promover impactos positivos. Ao contemplar a família de crianças e adolescentes como prioridade nas ações de políticas públicas, se distingue em muito de outras cidades que implementaram o programa. É um programa que retira a criança e/ou adolescente do trabalho infanto-juvenil e busca alcançar estratégias para que os mesmos não voltem ao mercado de trabalho. Para tanto, procura fortalecer seus três pilares básicos: a bolsa, a jornada ampliada e o atendimento à família.

Com isso, existe uma sensibilização maior por parte dos atores sociais que estão envolvidos com a questão do combate ao uso de mão de obra infanto-juvenil. A sociedade civil, os meios de comunicação, o poder público, o empresariado e os sindicatos estão mais atuantes, e uma de suas principais representações foi a Comissão de Erradicação do Trabalho Infantil (Cometi) ${ }^{27}$ que trouxe uma nova forma de enxergar a questão do trabalho da criança e do adolescente.

O papel da Prefeitura tem sido fundamental neste processo, tanto no que diz respeito ao complemento da bolsa do governo federal quanto no aumento do número de atendimentos. A implementação do Peti em Campinas foi realizada de maneira bastante cuidadosa e, ao estabelecer o programa como marca de governo, procurou-se durante estes quase 10 anos manter um modelo de ação junto às famílias. A criação do Programa Convivência e Cidadania também pode ser considerada um êxito, pois criou-se a partir dela uma rede de abordagem e referenciamento nunca vistos no município. Enfim, é visível a preocupação do órgão gestor com o sucesso do programa.

Sob este aspecto, o Peti/Campinas vai além do Peti/Brasil, pelo próprio valor da bolsa e com o trabalho intersetorial realizado pelas OGs e ONGs. Existe no município uma Rede de Proteção Social mínima que consegue atender a família de uma maneira abrangente, principalmente nas áreas de saúde e educação. Há um esforço de quase todos os agentes envolvidos na eliminação do uso exploratório da mão de obra infanto-juvenil que funciona dentro de certa sintonia capaz de enfrentar a questão com maior responsabilidade. Obviamente, seus

\footnotetext{
${ }^{27}$ A Cometi se organiza uma vez por mês para discutir todos os problemas, avanços e limites do próprio programa.
} 
limites já foram discutidos e é a partir deles que o órgão gestor tem de focar suas estratégias, de forma mais eficaz e condizente com a realidade local. As famílias, neste contexto, reconhecem a importância do Peti em suas vidas e alimentam expectativas cada vez maiores em relação às mudanças que possam vir a ocorrer. Um trabalho digno e mais bem remunerado ainda continua sendo o grande reconhecimento de sua cidadania.

\section{Conclusão}

Com relação ao perfil das famílias incluídas no programa, a análise dos dados quantitativos obtidos na pesquisa nos permitiu conhecer mais de perto suas características, cuja ênfase recaiu sobre aspectos como as características pessoais dos membros das famílias, além do grau de instrução e qualificação profissional dos responsáveis adultos pelas crianças e adolescentes. Tais informações foram agrupadas em torno da figura do pai, dos filhos, mas principalmente das mães.

A análise quantitativa do perfil das mães incluídas no Peti/Campinas nos deixa a percepção de que se trata de mulheres simples, com baixo nível de escolaridade, que passaram por diversos casamentos e possuem uma quantidade significativa de filhos, além de auferirem rendimentos ínfimos e de trabalharem em serviços precários. Enfim, representam a grande maioria das mulheres (mães) brasileiras de famílias pobres, as quais sobrevivem com muito pouco, mas que estão dispostas a mudar sua própria realidade, faltando-lhes na maioria das vezes a oportunidade.

A exemplo das mães, os pais também deveriam ser incorporados aos programas de qualificação profissional e de educação para adultos e, com isso, tornar a família menos dependente de programas de transferência de renda. Aliás, quando não existe a presença do pai no ambiente familiar, como é o caso de praticamente metade das famílias estudadas, as mães encontram-se em uma situação muito mais delicada e de maior vulnerabilidade, tendo que sustentar praticamente sozinhas toda a sua família e ver seus filhos ficarem cada vez mais expostos ao risco de entrar precocemente no mercado de trabalho.

Os filhos, por sua vez, antes da entrada no programa, trabalhavam nas mais diversas ocupações do comércio informal. É verdade que, apesar de terem trabalhado, na maior parte das vezes não abandonaram os estudos; todavia, existe uma defasagem idade-série significativa, notadamente entre os mais velhos.

As mudanças na vida das famílias incluídas no Peti/Campinas são nítidas, tanto em termos econômicos, quanto sociais e psicológicos. É um programa que, dentro de seus limites, está conseguindo combater o trabalho infanto-juvenil no município. A população está mais sensibilizada, o tema entrou definitivamente na agenda social, a Cometi realiza um trabalho exemplar no monitoramento e acompanhamento do programa. Os técnicos, tanto do Peti quanto do Convivência e Cidadania, demonstram-se altamente comprometidos com o tema. Enfim, existe um envolvimento manifesto do gestor municipal na continuidade e assertividade do programa. Porém, ainda patina em questões essenciais, como é o caso dos programas de 
geração de emprego e renda, pois sem um emprego digno para estas famílias teremos a perpetuação da sua dependência em relação ao nosso mínimo sistema de proteção social.

\section{Referências}

ABRAHAMSON, P. Welfare pluralism: para um novo consenso na política social europeia? Brasília, Neppos/Ceam/UnB, 1992.

ALENCAR, M.M. Transformações econômicas e sociais no Brasil dos anos 1990 e seu impacto no âmbito da família. In: SALES, M.A.; MATOS, M.C.; LEAL, M. (Org.). Política social, família e juventude: uma questão de direitos. São Paulo: Cortez, 2004.

BOURDIEU, P. A dominação masculina. Rio de Janeiro: Bertrand Brasil, 1999.

COSTA, José Vilton. Família e educação formal: um estudo sobre a frequência à escola e progressão escolar das crianças de 7 a 14 anos no município de Campinas. Dissertação (mestrado) — Instituto de Filosofia e Ciências Humanas, Universidade Estadual de Campinas/Campinas, 2005.

DI GIOVANNI, Geraldo. Trabalho infantil em Campinas. Campinas: Instituto de Economia (IE)/Unicamp, 2001. (Pesquisas n. 5)

FONSECA, Claudia. De família, reprodução e parentesco: algumas considerações. Cadernos Pagu, Campinas, n. 29, p. 9-35, 2007.

FONSECA, Ana Maria Medeiros da. Família e política de renda mínima. São Paulo: Cortez, 2001.

LEZCANO, R.S. Seleção entre e dentro de famílias de meios-irmãos no milho. Dissertação (mestrado) - Escola Superior de Agricultura "Luiz de Queiroz". Piracicaba: Esalq, 1998.

MOURA, Margarida Maria. Os deserdados da terra: a lógica costumeira e judicial dos processos de expulsão e invasão da terra camponesa no sertão de Minas Gerais. Rio de Janeiro: Bertrand Brasil, 1988.

PASQUINI, Ligia Pereira. Visão das famílias e usuários do Programa de Erradicação do Trabalho Infantil sobre o trabalho do serviço social. Trabalho de Conclusão de Curso. Pontifícia Universidade Católica de Campinas/Faculdade de Serviço Social. Campinas, 2005.

PEREIRA, Marcos; PEREIRA, Márcia. A questão da família. In: SEMINÁRIO SOBRE FAMÍLIA E POLÍTICAS PÚBLICAS, Fortaleza, 2004.

PEREIRA, P.A. Mudanças estruturais, política social e papel da família: crítica ao pluralismo de bem-estar. In: SALES, M.A.; MATOS, M.C. de; LEAL, M.C. (Org.). Política Social, famúlia e Juventude: uma questão de direitos. 2. ed. São Paulo: Cortez, 2004.

ROUDINESCO, Elisabeth. A família em desordem. Rio de Janeiro: Jorge Zahar, 2003.

SOUZA, Rosa Fátima de. O direito à educação. Campinas: Unicamp/Centro de Memória/Editora da Unicamp, 1998. 
TELLES, Vera da Silva. A experiência da insegurança: trabalho e família nas classes trabalhadoras urbanas em São Paulo. Tempo Social, São Paulo, v. 4. n. 1, p. 53-93, 1992.

UNICEF. Análise situacional do Programa de Erradicação do Trabalho Infantil — PETI. Brasília, maio 2004.

Elisiane Sartori é professora associada da Faculdade de Tecnologia de Indaiatuba, do Centro Estadual de Educação Tecnológica Paula Souza. E-mail: elisiane4@hotmail.com.

Carlos Henrique Menezes Garcia é professor associado e pesquisador da Faculdade de Tecnologia de Americana, do Centro Estadual de Educação Tecnológica Paula Souza. E-mail: cahenrique13@yahoo. com.br. 